\title{
The Impact of Transactional and Transformational Leadership Style on Organizational Citizenship Behaviors
}

\author{
Alexandra de Oliveira Rodrigues - Universidade Salgado de Oliveira, Rio de Janeiro, Brasil \\ Maria Cristina Ferreira - Universidade Salgado de Oliveira, Rio de Janeiro, Brasil
}

\begin{abstract}
We investigated the impact of transactional and transformational leadership styles on organizational citizenship behaviors. The sample consisted of 213 workers of both genders who answered the Multifactorial Leadership Scale and the Organizational Citizenship Behaviors (OCB) Scale. The multiple linear regression showed that: the transactional leadership style positively predicted the OCB dimension associated to the creation of a climate favorable to the organization in the external environment; the transformational leadership style positively predicted the dimensions of OCB associated to the creative suggestions related to the system; to the creation of a favorable organizational climate in the external environment; to self-training and to cooperation among colleagues; transformational leadership style showed greater predictive power on OCB than transactional leadership. It was concluded that transformational leaders are more capable to lead their subordinates in order to take actions that go beyond their prescribed roles.

Keywords: leadership, organizational behavior, organizations, citizenship
\end{abstract}

\section{O Impacto da Liderança Transacional e Transformacional sobre a Cidadania Organizacional}

\begin{abstract}
Resumo
Investigou-se o impacto dos estilos de liderança transacional e transformacional sobre os comportamentos de cidadania organizacional. A amostra foi composta por 213 trabalhadores de ambos os sexos, que responderam ao Questionário Multifatorial de Liderança e à Escala de Comportamentos de Cidadania Organizacional (CCO). As análises de regressão múltipla linear padrão evidenciaram que: o estilo de liderança transacional predisse positivamente a dimensão dos CCO associada à criação de clima favorável à organização no ambiente externo; o estilo de liderança transformacional predisse positivamente as dimensões dos CCO relacionadas às sugestões criativas ao sistema; a criação de clima favorável à organização no ambiente externo; o autotreinamento e à cooperação com os colegas; o estilo de liderança transformacional apresentou maior poder preditivo sobre os CCO que o estilo de liderança transacional. Concluiu-se que os líderes transformacionais mostram-se mais aptos a levarem seus subordinados a adotar ações que vão além de seus papéis prescritos.

Palavras-chave: liderança, comportamento organizacional, organizações, cidadania
\end{abstract}

El Impacto del Liderazgo Transaccional y Transformacional sobre la Ciudadanía Organizacional

\begin{abstract}
Resumen
Se investigó el impacto de los estilos de liderazgo transaccional y transformacional sobre los comportamientos de la ciudadanía organizacional. La muestra fue compuesta por 213 trabajadores de ambos sexos, que respondieron al Cuestionario Multifactorial de Liderazgo y a la Escala de Comportamientos de la Ciudadanía Organizacional (CCO). Los análisis de regresión múltiple lineal estándar evidenciaron que: el estilo de liderazgo transaccional predice positivamente la dimensión de los CCO asociada a la creación del clima favorable a la organización en el ambiente externo; el estilo de liderazgo transformacional predice positivamente las dimensiones de los CCO relacionadas a las sugestiones creativas al sistema; la creación del clima favorable a la organización en el ambiente externo, al auto entrenamiento y la cooperación con los compañeros; el estilo de liderazgo transformacional presentó mayor poder predictivo sobre los CCO, que el estilo de liderazgo transaccional. Se concluyó que los líderes transformacionales se muestran más aptos a llevar a sus subordinados a adoptar acciones que van más allá de sus papeles prescriptos. Palabras clave: liderazgo, comportamiento organizacional, organizaciones, ciudadanía
\end{abstract}

Leadership can be defined as the ability to motivate and influence the activities of groups of subordinates, in an ethical, respectful and loyal manner, so that they can contribute to the achievement of objectives the team and the organization hold in common (Hersey \& Blanchard, 1986). In recent decades, various leadership theories have been developed and empirically tested. More recently, however, one theory on which great research has been done is that of transformational versus transactional leadership (Bass, 1990). In transformational leadership, the leaders appoint goals that go beyond the short-term objectives and are concentrated on higher organizational needs. In transactional leadership, on the other hand, appropriate resource exchange in the short-term is the focus.

The transactional and transformational leadership styles have shown to be associated with various organizational outcomes, including satisfaction at work, commitment to work and productivity (Wang, Oh, Courtright, \& Colbert, 2011). In this research, the 
relations between the transactional and transformational leadership styles and the organizational citizenship behaviors are of particular interest.

The organizational citizenship behaviors can be defined as individual and discretionary acts, which the organization's formal reward system does not recognize direct or explicitly, and which promote its proper functioning (Organ,1997). These behaviors have been attracting scholars' interest as they have shown to be responsible for obtaining more motivated individuals with competences focused on effectively complying with the short and long-term organizational objectives (Rego, 2002).

Various recent studies (Babcock-Roberson \& Strickland, 2011; Cho \& Dansereau, 2010; Eboli, 2010; Humphrey, 2012; Lian \& Tui, 2012; Song, Kang, Shin, \& Kim, 2012; Suliman \& Obaidly, 2013; Wang et al., 2011) have verified the relationships between transactional and transformational leadership styles and the organizational citizenship behaviors. These studies, however, have been mainly conducted in foreign samples.

Nevertheless, existing differences in the cultural standards distinct societies have endorsed can influence the attitudes and behaviors manifested in the work context (Gelfand, Erez, \& Aycan, 2007). In the specific case of transformational and transactional leadership, two diverging positions can be found in the literature. One of them defends that the effectiveness of these leadership styles is universal, to the extent that the task of motivating and influencing the subordinates towards achieving the organizational objectives is part of the leaders' responsibilities in any culture (House, Hanges, Javidan, Dorfman, \& Gupta, 2004). Another position defends, nevertheless, that the cultural values influence the leadership phenomenon and, consequently, that the leadership styles in line with those values tend to be more effective (House, Dorfman, Javidan, Hanges, \& Luque, 2013; Leong \& Fischer, 2011). Similarly, earlier studies have demonstrated that cultural factors can stimulate or inhibit the practice of organizational citizenship behaviors (Paine \& Organ, 2000), and that these factors also tend to moderate the influence of the transformational and transactional leadership on those behaviors (Cavazotte, Hartman, \& Bahiense, 2014; Euwema, Wendt, \& Van Emmerik, 2007).

Therefore, additional studies are justified that are capable of contributing to a further understanding about the nature of the relationships between transformational and transactional leadership and the organizational citizenship behaviors in cultures that have not been sufficiently explored yet, like in the case of Brazil. Thus, in the literature survey undertaken in Brazilian databases (Scielo, Lilacs, Pepsic, CAPES), a single Brazilian study was located (Eboli, 2010) that was focused on the above mentioned relationships, which resulted from an unpublished Master's thesis. Based on these considerations, the general objective in this study was to identify the impact of the transactional and transformational leadership styles on the organizational citizenship behaviors.

\section{The Leadership Phenomenon}

The literature on leadership evidences that, for a long time, researchers in the area have been attempting to develop a concept for this phenomenon, although the authors who focus on the theme have not been able to reach a universal concept of this phenomenon yet. Nevertheless, the different definitions proposed for the leadership phenomenon highlight the fact that it is closely linked to the leader's intentional influence on the subordinates in certain situations (Fachada, 1998), which made Yukl (1998) affirm that this influence process is the essence of leadership.

In the course of the last decades, different theories have been developed to characterize leaderships, although the theory of transformational and transactional leadership is one of the most adopted theories nowadays to study the effectiveness of leadership (Piccolo \& Colquitt, 2006). According to Bass and collaborators (Bass, Avolio, \& Atwater, 1996; Bass, Avolio, Jung, \& Berson, 2003), transactional leaders motivate their followers to reach established targets by clarifying the roles and requirements of the tasks, as well as by adopting rewards or punishments, when the targets are reached or not. The transformational leaders, in turn, motivate their followers through communication and examples, attempting to inspire them and stimulate them intellectually, so that they execute their tasks both efficient and effectively.

According to the same authors (Bass et al., 1996; Bass et al., 2003), transactional leadership can be described in four dimensions: contingent reward - the leader clarifies the objectives, offers rewards for good performance and acknowledges accomplishments; active management by exception - the leader observes and looks for rewards and patterns, adopting corrective attitudes when necessary; passive management by exception - the leader intervenes only when the pre-established standards are not attended to; laissez-faire 
- the leader waives his responsibilities and avoids decision taking. Transformational leadership, in turn, is characterized by the following four dimensions: individual consideration - the leader grants personal attention and treats each employee individually, offering training and advice; intellectual stimulus - the leader stimulates the intelligence, rationality and careful problem solving; inspiration - the leader sets high expectations, uses symbols for his subordinates to concentrate efforts and expresses important purposes in a simple manner; charisma - the leader demonstrates vision and communicates the sense of his mission appropriately, thus gaining his subordinates' respect and trust, who become proud of having him as a leader. This model was adopted in this study to investigate the leadership styles.

\section{The Organizational Citizenship Behaviors}

The introduction of the expression organizational citizenship behaviors (OCB) in the literature on organizational studies is due to Organ and associates (Bateman \& Organ, 1983; Organ, 1997; Smith, Organ, $\&$ Near, 1983). Bateman and Organ (1983) characterize these behaviors as actions that are useful to the organization, which are neither imposed by the function nor induced by the guarantee of a reward, thus constituting informal contributions the individuals can decide to offer or reject, independently of sanctions or formal objectives. In this research, the OCB were considered as voluntary acts that go beyond the formally prescribed functions for a certain job and which contribute to the appropriate functioning of the organization.

One empirical research branch in the field on organizational citizenship behaviors has been focused on characterizing the dimensions of this construct, despite the fact that scholars have not been able to reach a consensus yet on its dimensions. In Brazil, in the study by Porto and Tamayo (2003), five dimensions of OCB were identified: (i) creative suggestions to the system refer to the behaviors of suggesting new ideas issued to benefit the organization; (ii) protection to the system - associated with producing actions aimed at protecting the organizational property; (iii) creation of a climate favorable to the organization in the external environment - related to the behaviors of disseminating the advantages and merits of the organization beyond the work environment; (iv) self-training - combines behaviors focused on seeking courses and events that can contribute to improve performance at work; (v) cooperation with colleagues - comprises behaviors of helping fellow workers aimed at benefiting the organization. The model under analysis was adopted to investigate the OCB in this study.

Transactional Leadership, Transformational Leadership and Organizational Citizenship Behaviors

In transactional leadership, the core characteristic is the relation of exchange established between leaders and subordinates. In that sense, the transactional leader clarifies the goals that are to be achieved and makes it clear that the successful achievement of these targets will imply rewards, while non-compliance with the targets will imply punishments (Bass et al., 1996; Bass et al., 2003). Hence, these leaders motivate their subordinates by establishing mutual agreements that, if effectively complied with over time, can be responsible for the subordinates' development of feelings of trust in the leader (Whittington, Goodwin, Coker, Ickes, \& Murray, 2009). This trust can make them engage in actions that go beyond the expectations about the targets that are to be achieved in function of their formal roles in the organization, leading the production of organizational citizenship behaviors. In that sense, some empirical evidence demonstrates that transactional leadership predicts the organizational citizenship behaviors (Asgari, Silong, Ahmad, \& Samah, 2008; Podsakoff, MacKenzie, Paine, \& Bachrach, 2000; Suliman \& Obaidly, 2013; Whittington et al., 2009). Based on these considerations, the following hypothesis was established:

H1 - The transactional leadership style positively predicts the organizational citizenship behaviors.

Transformational leaders, in turn, consider the individual needs of their subordinates and encourage them to prioritize the collective over the individual interests as a way to achieve the organizational targets and the wellbeing of the group (Bass et al., 1996; Bass et al., 2003). These behaviors highlight the standard of reciprocity (Blau, 1964), which makes the subordinates engage in a process of social exchanges with their leaders (Goodwin, Wofford, \& Whittington, 2001), that is, it brings them to make efforts in favor of the organization, as a way to return the treatment received by their leaders (Boerner, Eisenbeiss, \& Griesser, 2007). Thus, they start to identify with the organizational targets and share a collective identity that promotes the production of behaviors focused on promoting the common good, which characterize the organizational citizenship behaviors, like helping colleagues for example, overcoming challenges for the benefit of the common good and 
engaging in functions that are not directly associated with the prescribed tasks. In that sense, a considerable amount of empirical studies, undertaken in different occupational contexts (Asgari et al., 2008; Boerner et al., 2007; Eboli, 2010; Lian \& Tui, 2012; Nguni, Sleegers, \& Denesen, 2006; Omar, Zainal, Omar, \& Khairudin, 2009; Piccolo \& Colquit, 2006; Suliman \& Obaidly, 2013), as well as recent meta-analyses (Wang et al., 2011), have appointed that the transformational leadership styles are positive predictors of OCB. Nevertheless, these relations have shown to be more prominent in collective cultures (Euwema et al., 2007). Therefore, based on these considerations, the following hypothesis was formulated:

H2 - The transformational leadership style positively predicts the organizational citizenship behaviors.

According to Bass (1985), true leaders should present both transactional and transformational leadership behaviors, as these represent complementary styles. Nevertheless, the author defends that the positive predictive power of the transformational leadership style on the OCB is higher while, in principle, the transactional leadership style is limited to exchanges between the leader and subordinates related to the behaviors expected for the function, despite the fact that, over time, the leader can elicit behaviors that go beyond the expectations for that function. The core characteristic of the transformational leadership style, on the other hand, is the increase in the subordinates' level of motivation and self-esteem, which would naturally imply actions in favor of the organization not limited to the performance of the roles prescribed for the function. In that sense, different studies (Mackenzie, Podsakoff, \& Rich, 2001; Omar et al., 2009; Zabihi \& Hashemzehi, 2012) and meta-analyses (Wang et al., 2011) have evidenced the stronger power of the transformational leadership style to explain the OCB than the transactional leadership style. There is no consensus on these results though, as other studies have concluded that transactional leadership has greater predictive power on the OCB when compared to transformational leadership (Suliman \& Obaidly, 2013; Whittington et al., 2009). Other studies have observed that neither transactional nor transformational leadership directly affect the OCB (Dai, Dai, Chen, \& Wu, 2013). These contradictory results can be due to the fact that these different studies were conducted in distinct cultural contexts, as earlier evidences indicate that the influence of these two leadership styles on the OCB is moderated by cultural factors (Cavazotte et al., 2014; Euwema et al., 2007). Therefore, in view of the theory by Bass (1985), the following research hypothesis was formulated:

H3 - The transformational leadership style has greater predictive power on the OCB than the transactional leadership style.

\section{Method}

\section{Participants}

A convenience sample was adopted. About 400 questionnaires were distributed to the employees of four food industry and trade organizations, mainly located in the Baixada Fluminense, State of Rio de Janeiro, as one of the authors had contacts inside these organizations. In total, 213 questionnaires were returned, corresponding to a return rate of $53.2 \%$. The participants were predominantly male (56.3\%), between 18 and 51 years of age (mean $=28.66$ years; standard deviation $=7.29$ years). As regards the marital status, $49.8 \%$ were single and, concerning education, $46.5 \%$ had either finished or not finished higher education. The length of work at the company ranged between one and 25 years (mean $=4.08$ years of work; standard deviation $=3.42)$. What the position in the company is concerned, administrative/operational functions prevailed $(70.4 \%)$.

\section{Instruments}

To assess the leadership styles, the short version of the Multifactor Leadership Questionnaire (MLQ$-5 \mathrm{X})$, developed by Avolio and Bass (2004), was used. The Portuguese version of the questionnaire was purchased directly from the Editor Mind Garden (www.mindgarden.com) and is protected by copyright, which is why its items are not fully displayed in the text. Examples of the items include: "Reexamines critical premises to check whether they are appropriate" (transformational leadership); "Focuses on irregularities, errors, exceptions and expected standard deviations (transactional leadership)".

The questionnaire consists of 36 items, to be answered on five-point Likert scales, ranging from never (0) to frequently (4), according to how the respondent perceives the behavioral characteristics of his immediate head. These items are grouped in six factors, distributed across three scales. The transformational leadership scale consists of three factors (charisma, intellectual stimulus and individualized consideration) and the transactional leadership scale 
of two factors (active management by exception and contingent reward), while the laissez-faire leadership scale comprises a single factor (passive avoidance). Confirmatory factorial analysis procedures, applied to a sample of 3786 respondents from different countries and occupations, confirmed the six-factor structure of the tool, whose internal consistency coefficients ranged between 0.63 (active management by exception) and 0.92 (charisma). In addition, different studies have joined evidence on the predictive validity of the tool through the use of different criterion measures, like organizational commitment and intra and extra-role performance (Avolio \& Bass, 2004). In this study, only the transactional and transformational leadership scales were included. In view of the lack of earlier studies on evidences of the validity of the tool in Brazilian samples, this had to be verified, before the research hypotheses could be tested.

To assess the organizational citizenship behaviors, the Organizational Citizenships Behavior Scale, developed by Porto and Tamayo (2003), was used. The tool consists of 41 items, to be answered on five-point scales, ranging from never (0) to always (4), according to the respondents' actions with regard to their organization. These items are divided in five factors: creative suggestions to the system (13 items); protection to the system (seven items); creation of a climate favorable to the organization in the external environment (eight items); self-training (four items); cooperation with colleagues (nine items). Examples of the items are: "I give suggestions to solve problems in the sector where I work" (creative suggestions to the system), "I try to defend my organization" (protection to the system), "I try to transmit the best impressions to people who do not know this organization" (creation of a climate favorable to the organization in the external environment), "I try to take part in professional recycling courses" (self-training), "I offer help to colleagues who are burdened" (cooperation with colleagues). In the construction of this tool, exploratory factorial analysis procedures were adopted, which originated the five factors of the scale, with internal consistency coefficients ranging from 0.80 (protection to the system) to 0.91 (creative suggestions to the system) (Porto \& Tamayo, 2003). In this study, the reliability coefficients of these scales, obtained using Cronbach's Alpha, corresponded to $0.89 ; 0.61 ; 0.92 ; 0.80$ and 0.81 , respectively. The data collection tool also included questions on the participants' sociodemographic characteristics and the free and informed consent form.

\section{Procedure}

Initially, the research project was submitted and received approval from the Institutional Review Board at Universidade Salgado de Oliveira. Then, the managers and other workers of different food industry organizations in one of the authors' contact network were contacted. In some cases, the managers gave permission to develop the research and joined their teams, asked them to complete the printed questionnaires and collected them at the end. Another part of the data collection was undertaken through direct contact with the workers who, after accepting to contribute to the research, received the data collection tools and, soon after their completion, returned them directly to one of the authors. The confidentiality and anonymity of the answers were guaranteed to all participants.

\section{Results}

\section{Validity Evidence of Multifactorial Leader- ship Questionnaire (MLQ)}

In the search for evidence on the validity of the MLQ, initially, the premises of the exploratory factorial analysis were verified. The Kaiser-Meyer-Olkin (KMO) measure was equal to 0.92 , indicating that the data were appropriate for analysis. Similarly, Bartlett's sphericity test was significant $\left(\chi^{2}=3977.35 ; p<0.001\right)$, evidencing that the correlations between the items permitted the factorial analysis.

In that sense, the inter-correlation matrix among the items was initially submitted to the principal component analysis, which extracted five factors with eigenvalues superior to 1 , responsible for $61.0 \%$ of the total variation in the tool. In addition, the screeplot revealed two to four interpretable factors at most.

Thus, additional factorial analyses were developed through the principal axis factor and oblique rotation method, with an anticipated solution of two to four factors. These analyses evidenced that the two-factor solution best represented the internal structure of the questionnaire, having explained $45.0 \%$ of the total variation in the tool. Thus, the items were retained with factor loadings superior to 0.30 in a single factor and which demonstrated conceptual similarity with the other items in the factor.

Factor 1 consisted of nine items and was called transformational leadership, as it contained assertions 
associated with charisma, individualized consideration and intellectual stimulation. Factor 2 consisted of five items associated with active management by exception and contingent reward, characteristics of transactional leadership. Table 1 displays the factor loadings of the items in these factors and their internal consistency coefficients.

In summary, the final version of the Multifactorial Leadership Questionnaire (MLQ) used in this research consisted of 14 items, distributed in two factors. It is corrected towards the dimension assessed. Thus, the higher the score obtained on each subscale, the higher the incidence of that dimension in the organization. All subsequent analyses were developed using that version of the scale.

\section{Test of Research Hypotheses}

In Table 2, the means, standard deviation and correlations between the scales are displayed. To verify the predictive power of the transactional and transformational leadership styles on the organizational citizenship behaviors, five multiple linear regression analyses were developed, in which the two leadership styles served as the predictive variables and the different citizenship factors as the criterion variable. What the factor associated with the creative suggestions to the system is concerned, the model was significant and explained $12 \%$ of

Table 1

Factor Loading of Items in the Transformational and Transactional Leadership Scales

\begin{tabular}{lcc}
\hline Items & F1 & F2 \\
\hline 31 & 0.84 & \\
15 & 0.78 & \\
30 & 0.79 & \\
10 & 0.82 & \\
18 & 0.66 & \\
29 & 0.61 & \\
32 & 0.80 & \\
23 & 0.70 & \\
2 & 0.66 & \\
27 & & 0.58 \\
4 & & 0.37 \\
22 & & 0.34 \\
11 & & 0.29 \\
24 & & 0.29 \\
$\alpha$ & & 0.71 \\
\hline
\end{tabular}

the variance in the criterion variable. Nevertheless, only the transformational leadership was a positive and significant predictor of this criterion variable (Table 3).

Concerning the protection to the system, the regression model was significant but explained only $3 \%$ of the variance in the criterion variable. In addition, none of the two predictors showed significance (Table 3). As regards the creation of a climate favorable to the organization in the external environment factor, the model was significant and explained $26 \%$ of the variance in the criterion variable. In this model, both transformational and transactional leadership served as positive and significant predictors of the criterion variable, although transformational leadership obtained a higher predictive power (Table 3).

In the analysis of the self-training factor, the regression model demonstrated significance and explained $13 \%$ of the variance in the criterion variable. Nevertheless, only transformational leadership was a positive and significant predictor of this dependent variable (Table 3).

In the regression analysis using the cooperation with colleagues factor, finally, the regression model was significant but explained only $10 \%$ of the variance in the criterion variable. Nevertheless, transformational leadership showed to be a positive and significant predictor of this variable (Table 3).

\section{Discussion}

The general objective in this research was to investigate the impact of the transactional and transformational leadership styles on the organizational citizenship behaviors. The multiple regression analyses evidenced that the transactional leadership style positively and significantly predicted the OCB dimension associated to the creation of a climate favorable to the organization in the external environment only, which partially confirms Hypothesis 1. Thus, it was verified that, in this sample, the leadership style based on relations of exchange and rewards between leaders and subordinates (Bass, 1990) was only effective to predict the behaviors associated with the dissemination of a good organizational image in its external environment. These results are consistent with different earlier studies (Asgari et al.,2008; Podsakoff et al., 2000; Suliman \& Obaidly, 2013; Whittington et al., 2009) that also found the predictive power of transactional leadership on the OCB. 
Table 2

Means, Standard Deviations and Correlation Coefficients between OCB and Leadership Styles

\begin{tabular}{|c|c|c|c|c|c|c|}
\hline MD SD & 1 & 2 & 3 & 4 & 5 & 6 \\
\hline 1. 2.461 .02 & & & & & & \\
\hline 2. 2.560 .82 & $0.65^{* *}$ & 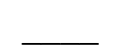 & & & & \\
\hline 3. 2.940 .63 & $0.34 * *$ & $0.25^{* *}$ & $\longrightarrow$ & & & \\
\hline 4. 3.450 .58 & $0.17 * *$ & $0.17 * *$ & $0.52^{* *}$ & - & & \\
\hline 5. 3.010 .83 & $0.47 * *$ & $0.40 * *$ & $0.66^{* *}$ & $0.48^{* *}$ & $\ldots$ & \\
\hline 6. 2.630 .96 & $0.35^{* *}$ & $0.28^{* *}$ & $0.46^{* *}$ & $0.27 * *$ & $0.45^{* *}$ & 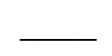 \\
\hline 7. 3.310 .52 & $0.32 * *$ & $0.20 * *$ & $0.70^{* *}$ & $0.51^{* *}$ & $0.56^{* *}$ & $0.32 * *$ \\
\hline
\end{tabular}

$* * p<0.01$

Transformational leadership; 2. Transactional leadership; 3. Creative suggestions to the system; 4. Protection to the system; 5 . Creation of climate favorable to the organization in the external environment; 6. Self-training; 7.Cooperation with colleagues.

Table 3

Multiple Linear Regression of Leadership Styles on Organizational Citizenship Behaviors

\begin{tabular}{lccccc}
\hline $\begin{array}{l}\text { Predictive } \\
\text { variables }\end{array}$ & $\begin{array}{c}\text { Creative } \\
\text { suggestions } \\
\text { to the system }\end{array}$ & $\begin{array}{c}\text { Protection to } \\
\text { the system }\end{array}$ & $\begin{array}{c}\text { Creation of climate } \\
\text { favorable to organization in } \\
\text { external environment }\end{array}$ & $\begin{array}{c}\text { Self-training } \\
\text { with colleagues }\end{array}$ \\
\hline $\begin{array}{l}\text { Transformational } \\
\text { leadership }\end{array}$ & $0.30^{* *}$ & 0.11 & $0.38^{* *}$ & $\beta$ & $\beta$ \\
$\begin{array}{l}\text { Transactional } \\
\text { leadership }\end{array}$ & 0.08 & 0.11 & $0.18^{*}$ & $0.30^{* *}$ & $0.31^{* *}$ \\
& & & & 0.10 & 0.02 \\
$\begin{array}{l}\text { Adjusted } R^{2} \\
F\end{array}$ & 0.12 & 0.02 & 0.26 & 0.13 & 0.10 \\
& $14.79^{* *}$ & 0.15 & $37.28^{* *}$ & $16.83^{* *}$ & $11.94^{* *}$ \\
\hline
\end{tabular}

$* p<0.01 ; * *<0.001$

Transactional leadership basically rests on rewarding appropriate behaviors and punishing counterproductive behaviors (Bass, 1999). Thus, it is related to links of exchange, of giving and receiving between leaders and subordinates. Therefore, the subordinates are motivated by the leader's promises or are, on the opposite, corrected by the negative feedback, by rejections or by disciplinary actions. In that sense, the transactional leadership style tends to make the subordinates become loyal and obedient to their organization (Bass, 1985). The behavior of creating a climate favorable to the organization in the external environment, in turn, is associated with behaviors of disclosing the organization's advantages and merits beyond the work environment (Porto \& Tamayo, 2003), which can be interpreted as a behavior of loyalty to the organization. Thus, one would expect transactional leadership to serve as a predictor of this behavior, which actually happened.

As regards the transformational leadership style, the data demonstrated that this style positively and significantly predicted the OCB dimensions related to offering creative suggestions to the system, to creating a climate favorable to the organization in the external environment, to self-training and to cooperation with fellow workers. These findings almost fully confirm 
Hypothesis 2 and are also consistent with different studies (Asgari et al., 2008; Boener et al., 2007; Eboli, 2010; Lian \& Tui, 2012; Nguni et al., 2006; Omar et al., 2009; Piccolo \& Colquitt, 2006) that have also demonstrated the efficacy of the transformational leadership style to positively predict the OCB.

The transformational leaders tend to motivate their subordinates to surpass the expectations (Bass, 1985), adopting, for example, attitudes and behaviors that go beyond the individual interests and prioritize the collective causes (Eboli, 2010). Thus, it is understandable that this leadership style constituted a strong predictor of the behaviors to create a climate favorable to the system, as this kind of behavior, above all, benefits the organization collectively (Podsakoff et al., 2000).

Another characteristic of transformational leaders is the fact that they grant their subordinates autonomy and encourage them to cope with the problems as a way to enhance their performance and efficacy (Bass et al., 2003). Consequently, the subordinates would be expected to demonstrate a stronger trend to present creative suggestions to the system, as they feel more autonomous and independent to propose solutions that help them to cope with the difficulties and contribute to increase their performance, which would include the presentation of creative suggestions.

Transformational leaders can also be considered as agents of change, as they attempt to develop and transform the attitudes and beliefs of their subordinates (Bass, 1985), through the adoption of strategies that are capable of making them more aware of their needs for accomplishment, self-recycling and wellbeing (Bass, 1990). In that sense, it is predictable that they positively influenced the OCB dimension associated with self-training, as this behavior is characterized by actions related to the individual search for training offered internal or externally to the organization (Katz \& Kahn, 1978), as a way for the individuals to improve their performance and feel more fully accomplished as persons and professionals.

Finally, the transformational leaders tend to develop actions aimed at integrating, coordinating and facilitating the activities of their subordinates (Bass, 1990). Hence, they play a fundamental role in the creation of a cooperative environment (Eboli, 2010), which explains the fact that this leadership style constituted a positive predictor of behaviors of cooperation with colleagues, as this behavior corresponds to discretionary actions that are aimed at helping people with specific tasks (Organ, 1997).

In summary, the transformational leaders gain their subordinates' trust and admiration (Piccolo \& Colquitt, 2006). Based on this relationship of trust, they are able to promote high levels of identification and commitment of their subordinates to their own objectives as leaders and to the organizational objectives (Bass, 1999). It is through these processes that the transformational leader will probably promote the organizational citizenship behaviors, thus achieving more engaged and altruistic subordinates who are more willing to contribute to their organizations, through actions that go beyond their prescribed roles (Podsakoff et al., 2000).

It was also observed that transformational leadership demonstrated greater power to predict four of the OCB dimensions when compared to transactional leadership, which almost fully confirmed Hypothesis 3. These results are in line with different studies (Mackenzie et al., 2001; Omar et al., 2009; Zabihi \& Hashemzehi, 2012; Wang et al., 2011) that have highlighted the fact that, although both leadership styles (transformational and transactional) positively influenced the OCB, it is transformational leadership that is most strongly related to the OCB.

According to Bass (1985), the transformational leaders exert stronger influence processes than the transactional leaders because the latter remain limited to reacting to the problems when they receive them, that is, they only try to solve them to achieve preset objectives. When confronted with problems, on the opposite, the transformational leaders question them, with a view to contributing to the construction of a collective objective. In other words, the transformational leaders are more proactive, because they work to enhance the development and innovation of the individual, group and organization, instead of merely achieving the expected performance (Avolio \& Bass, 2004). Consequently, they show to be more capable of arousing their subordinates' organizational citizenship behaviors than the transactional leaders. In short, the transformational leaders usually reveal to be more capable of originating organizational change by stimulating higher levels of organizational citizenship in their subordinates when compared to the transactional leaders (Podsakoff, MacKenzie, Morrman, \& Fetter, 1990). 


\section{Final Considerations}

This study intended to investigate the impact of the transactional and transformational leadership styles on the organizational citizenship behaviors. The results obtained demonstrated that: the transactional leadership style positively predicted the OCB dimension associated with the creation of a climate favorable to the organization in the external environment; the transformational leadership style predicted all dimensions of the OCB, except for the dimension associated with the protection of the system; the transformational leadership style demonstrated greater power to predict the OCB when compared to the transactional leadership style.

Based on these results, some suggestions can be elaborated and maybe implemented in the future, with a view to strengthening the subordinates' organizational citizenship behaviors. As the evidence found here demonstrated that transformational leadership behaviors can more strongly influence the $\mathrm{OCB}$, it would be interesting for the organizations interested in enhancing their members' OCB to develop strategies aimed at showing their managers the importance of adopting these transformational behaviors, through training and qualification programs for managers, workshops, lectures and seminars, as a way to gain their team's trust and increase their level of safety and stability, granting them a work environment that makes them produce more OCB.

As regards a future research agenda, mediation studies should be developed, which can further the understanding of the mechanisms through which the leadership behaviors influence the organizational citizenship actions. In addition, other studies of the same kind in specific professional samples can also contribute to further the knowledge about the relations between the leadership styles and the organizational citizenship behaviors in Brazilian samples.

Finally, the limitations in this research should be highlighted. The fact that it was mostly developed in the state of Rio de Janeiro only reduces its generalizability. A second limitation refers to the fact that a single type of informant (the subordinates) answered the questions about the leader and subordinates. Thus, the common method variance may have affected the results obtained. Finally, the answers may have been the socially most acceptable ones instead of the most sincere answers, considering that, in some organizations, the leaders asked their subordinates to answer the questionnaires, which may have made them choose answers that would not compromise them. Nevertheless, it can be concluded that this research is of theoretical and practical importance, as a model was proposed and tested that included variables hardly explored in Brazilian samples.

\section{References}

Asgari, A., Silong, A. D., Ahmad, A., \& Samah, B. A. (2008). The relationship between leader-member exchange, organizational inflexibility, perceived organizational support, interactional justice and organizational citizenship behavior. African Journal of Business Management, 2(8), 138-145. Retrieved from http://www.researchgate.net/ publication/265510979_The_Relationship_between_Transformational_Leadership_Behaviors_Organizational_Justice_Leader-Member_Exchange_Perceived_Organizational_Support_ Trust_in_Management_and_Organizational_Citizenship_Behaviors

Avolio, B. J., \& Bass, B. M. (2004). MLQ Multifactor leadership questionnaire (3rd ed.). Redwood, CA: Mind Garden.

Babcock-Roberson, M. E., \& Strickland, O. J. (2010). The relationship between charismatic leadership, work engagement, and organizational citizenship behaviors. The Journal of Psychology, 144(3), 313-326 doi: 10.1080/00223981003648336.

Bass, B. M. (1985). Leadership and performance beyond expectations. New York, N.Y: Free Press.

Bass, B. M. (1990). Concepts of leadership. In J. T. Wren., D. A. Hicks. \& T. L. Price (Eds.), New perspectives on leadership (pp. 3-20). Northampton, MA: Edward Elgar.

Bass, B. M. (1999). Two decades of research and development in transformational leadership. European Journal of Work and Organizational Psychology, 8(1), 9-32. doi: 10.1080/135943299398410

Bass, B. M., Avolio, B. J., \& Atwater, L. (1996). The transformational and transactional leadership of men and women. Applied Psycology: An International Review, 45(1), 5-34. doi: 10.1111/j.1464-0597.1996. tb00847.x

Bass, B. M., Avolio, B. J., Jung, D. I., \& Berson, Y. (2003). Predicting unit performance by assessing 
transformational and transactional leadership. Journal of Applied Psychology, 88(2), 207-218. Retrieved from http://www.apa.org/pubs/journals/releases/apl-882207.pdf

Bateman, T. S., \& Organ, D. W. (1983). Job satisfaction and the good soldier: The relationship between affect and employee "citizenship." Academy of Management Journal, 26(4), 587-595. Retrieved from http://www.jstor.org/stable/255908

Blau, P. M. (1964). Exchange and power in social life. New York, NY: Wiley.

Boerner, S., Eisenbeiss, S. A., \& Griesser, D. (2007). Follower behavior and organizational performance: The impact of transformational leaders. Journal of Leadership \& Organizational Studies, 13(3), 15-26. doi: 10.1177/10717919070130030201

Cavazotte, F, Hartman, N. S., \& Bahiense, E. (2014). Charismatic leadership, citizenship behaviors, and power distance orientation: Comparing Brazilian and U.S. workers. Cross-Cultural Research, 48(1), 3-31. doi: 10.1177/1069397113494687

Cho, J., \& Dansereau, F. (2010). Are transformational leaders fair? A multi-level study of transformational leadership, justice perceptions, and organizational citizenship behaviors. The Leadership Quarterly, 21(3) 409-421. Retrieved from http://www.sciencedirect.com/science/article/pii/S1048984310000548

Dai, Y.D, Dai, Y.Y., Chen, K. Y., \& Wu, H. C. (2013). Transformational vs transactional leadership: Which is better? International Journal of Contemporary Hospitality Management, 25(5), 760-778. doi: 10.1108/IJCHM-Dec-2011-0223

Eboli, C. M. R. (2010). Liderança autêntica, transformacional e orientada para resultados: Um estudo de seus efeitos interativos sobre o desempenho individual [Authentic, transformational and oriented to results leadesrship: A study of its interactive effects on individual performance] (Unpublished Master's Thesis). Faculdade de Economia e Finanças IBMEC, Rio de Janeiro, Brasil.

Euwema, M. C., Wendt, H., \& Van Emmerik, H. (2007). Leadership styles and group organizational citizenship behavior across cultures. Journal of Organizational Behavior, 28(8), 1035-1057. doi: 10.1002/job.496
Fachada, O. (1998). Psicologia das relações interpessoais. [Interpersonal relationship psychology]. Lisboa: Edições Rumo.

Gelfand, M. J., Erez, M., \& Aycan, Z. (2007). Crosscultural organizational behavior. Annual Review of Psychology, 58, 479-514. Retrieved from http:// www.gelfand.umd.edu/pages/papers/Gelfandetal2007.pdf

Goodwin, V. L., Wofford, J. C., \& Whittington, J. L. (2001). A theoretical and empirical extension of transformational leadership construct. Journal of Organizational Behavior, 22(7), 759-776. doi: 10.1002/job.111

Hersey, P., \& Blanchard, K. H. (1986). Psicologia para administradores: A teoria $e$ as técnicas da liderança situacional. [Psychology for managers: Situational leadership's theory and techniques]. São Paulo: Editora Pedagógica Universitária.

House, R. J., Dorfman, P., Javidan, M., Hanges, P. W., \& Sully De Luque, M. (2013). Strategic leadership across borders: The GLOBE study of CEO leadership behavior and effectiveness in 24 countries. Thousand Oaks, CA: Sage.

House, R. J., Hanges, P. J., Javidan, M., Dorfman, P. W., \& Gupta, V. (2004).Culture, leadership, and organizations: The GLOBE study of 62 societies. ThousandOaks, CA: Sage.

Humphrey, A. (2012). Transformational leadership and organizational citizenship behaviors: The role of organizational identification. The Psychologist-Manager Journal, 15(4), 247-268. doi: 10.1080/10887156.2012.731831

Katz, D., \& Kahn. R. L. (1978). Psicologia social das organizações [Social psychology of organizations]. (A. Simões, Trad.). São Paulo: Atlas.

Leong, L. Y. C., \& Fischer, R. (2011). Is transformational leadership universal? A metaanalytical investigation of multifactor leadership questionnaire means across cultures. Journal of Leadership \& Organizational Studies, 18(2), 164-174. doi: 10.1177/1548051810385003

Lian, L. K., \& Tui, L. G. (2012). Leadership styles and organizational citizenship behavior: The mediating effect of subordinates competence and downward influence tactics. Journal of Applied Business and Economics, 13(2), 59-96. Retrieved from http:// 
www.na-businesspress.com/JABE/LianLK_ Web13_2_.pdf

MacKenzie, S. B., Podsakoff, P. M., \& Rich, G. A. (2001). Transformational and transactional leadership and salesperson performance. Journal of the Academy of Marketing Science, 29(2), 115-134. Retrieved from http://link.springer.com/article/10. 1177\%2F03079459994506

Nguni, S., Sleegers, P., \& Denessen, E. (2006). Transformational and transactional leadership effects on teachers' job satisfaction, organizational commitment, and organizational citizenship behavior in primary schools: The Tanzanian case. School Effectiveness and School Improvement, 17(2), 145-177. doi: 10.1080/09243450600565746

Omar, Z., Zainal, A., Omar, F., \& Khairudin, R. (2009). The influence of leadership behavior on organizational citizenship behavior in self-managed work teams in Malaysia. South African Journal of Human Resource Management, 7(1), 1-11. doi: 10.4102/sajhrm.v7i1.209

Organ, D. W. (1997). Organizational citizenship behavior: It's construct cleanup time. Human Performance, 10(2), 85-97. doi: 10.1207/s15327043hup1002_2

Paine, J. B., \& Organ, D. W. (2000). The cultural matrix of organizational citizenship behavior: Some preliminary conceptual and empirical observations. Human Resource Management Review, 10(1), 45-59. doi: 10.1016/S1053-4822(99)00038-8

Piccolo, R. F., \& Colquitt, J. A. (2006). Transformational leadership and job behaviors: The mediating role of core job characteristics. Academy of Management Journal, 49(2), 327-340. doi: 10.1.1.454.7623

Podsakoff, P. M., MacKenzie, S. B., Moorman, R. H., \& Fetter, R. (1990). Transformational leader behaviors and their effects on followers' trust in leader, satisfaction, organizational citizenship behaviors. The Leadership Quarterly, 1(2), 107-142. doi: 10.1016/1048-9843(90)90009-7

Podsakoff, P. M., MacKenzie, S. B., Paine, J. B., \& Bachrach, D. G. (2000). Organizational citizenship behaviors: A critical review of the theoretical and empirical literature and suggestions for future research. Journal of Management, 26(3), 513-563. doi: $10.1177 / 014920630002600307$
Porto, J. B., \& Tamayo, A. (2003). Desenvolvimento e validação da escala de civismo nas organizações [Development and validation of the organizational civism scale]. Estudos de Psicologia, 8(3), 393-402. doi: 10.1590/S1413-294X2003000300006

Rego, A. (2002). Climas éticos e comportamentos de cidadania organizacional [Ethical climates and organizational citizenship behaviors]. Revista de Administração de Empresas, 42(1), 50-63. Retrieved from http://www.scielo.br/pdf/rae/v42n1/v42n1a06. pdf

Smith, A., Organ, D. W., \& Near, J. (1983). Organizational citizenship behavior: Its nature and antecedents. Journal of Applied Psychology, 68(4), 653663. doi: 10.1037/0021-9010.68.4.653

Song, J. H., Kang, I. G., Shin, Y. H., \& Kim, H. K. (2012). The impact of an organization's procedural justice and transformational leadership on employees' citizenship behaviors in the Korean business context. Journal of Leadership \& Organizational Studies, 19(4) 424-436. doi: 10.1177/1548051812446659

Suliman, A., \& Obaidly, H. A. (2013). Leadership and organizational citizenship behavior (OCB) in the financial service sector: The case of the UAE. Asia-Pacific Journal of Business Administration, 5(2), 115-134. doi: 10.1108/17574321311321603

Wang, G., Oh, I., Courtright, S. H., \& Amy E. Colbert, A. E. (2011). Transformational leadership and performance across criteria and levels: A meta-analytic review of 25 years of research. Group \& Organization Management, 36(2) 223-270. doi: $10.1177 / 1059601111401017$

Whittington, J. L., Coker, R. H., Goodwin, V. L., Ickes, W., \& Murray, B. (2009). Transactional leadership revisited: Self-other agreement and its consequences. Journal of Applied Social Psychology, 39(8), 1860-1886. doi: 10.1111/j.1559-1816.2009.00507.x

Yulk, G. (1998). Leadership in organizations. New Jersey, NJ: Prentice Hall.

Zabihi, M., \& Hashemzehi, R. (2012). The relationship between leadership styles and organizational citizenship behavior. African Journal of Business Management, 6(9), 3310-3319. doi: 10.5897/AJBM11.2809

Recebido: 07/07/2014

Primeira reformulação: 11/02/2015

Aprovado: 19/03/2015 
Sobre as autoras:

Alexandra de Oliveira Rodrigues é psicóloga e mestre em Psicologia, com atuação em organizações. Atualmente é docente no ensino superior e profissionalizante militar do Departamento de Educação e Cultura do Exército, desenvolvendo a implantação do Ensino por Competências como Oficial Técnica.

E-mail: alexandra.psique@gmail.com

Maria Cristina Ferreira. Psicóloga, é mestre e doutora em Psicologia, com atuação na área de organizações. É atualmente professora titular e coordenadora do Programa de Pós-Graduação em Psicologia da Universidade Salgado de Oliveira (UNIVERSO).

E-mail:mcris@centroin.com.br

\section{Contato com as autoras:}

Maria Cristina Ferreira

E-mail:mcris@centroin.com.br

Rua Marquês de Valença, 80 apt 602 - Tijuca - Rio de Janeiro/RJ

CEP: 200.550-030 